\title{
Application of STAD Cooperative Learning of Primary
}

\author{
Atik Miftachul Rohmah, Yatim Riyanto, Rr. Nanik Setyowati \\ Universitas Negeri Surabaya \\ Surabaya, Indonesia \\ atikmifta58@gmail.com
}

\begin{abstract}
Based on observations made by researchers in class IIc SDN Klakahrejo I-578 Surabaya, some problems were found including that learners did not concentrate on learning and were passive in groups while the teachers did not use learning model. $67 \%$ students did not complete the materials. To improve these problems, teachers need to apply STAD video-assisted media. This is a classroom action research conducted in two cycles. The cycle begins with preliminary. Each cycle consists of planning, action/observation, reflection, and revision. The finding shows that the implementation of video-assisted $S T A D$ can improve learners' learning activities and outcomes. In the first cycle, students' activity reached $78.25 \%$, and classical completeness reached $73 \%$. In the second cycle, students' activity is $84.03 \%$ while the learning outcomes is only $83 \%$.
\end{abstract}

Keywords - video-assisted; STAD; activity; learning outcomes.

\section{INTRODUCTION}

Based on the observations made on the subtheme of 'diversity of individual characteristics at school', there are several factors that cause the low success of learning objectives. Factors causing the lack of success of learning objectives are explained as follows.

First, student had low concentration in the classroom. As the teacher explains the material, students played on their own. In group discussion activities, many learners were chatting with friends and playing stationery. In addition, when students received questions, some learners did not respond. Even when there were peer presentations, some learners sharpened their pencils. Thus, the learners' activity was still low.

Second, teachers implemented learning using group discussion methods, however, some learners were still passive in groups and some learners dominated group activities while teachers had reminded them to help each other against group members who had not mastered the materials. Learners' activity was also still low. As an effort to improve the activities of learners in learning activities, it is necessary to re-establish learning groups in accordance with cooperative learning groups.

Third, the teacher did not use learning model. To achieve the learning objectives, teachers transfer information and facilitate learners need to be carried out by using various models that match the material and characteristics of learners. More research is needed on the various methods. The more studies conducted on a method, the more accurate the effect size may be. Conclusions about methods that have only a few validating studies could be misleading [1]. Cooperative learning activities provide a context in which students may be more likely to interact than in a whole class setting [2].

The set minimum score was 75 and there were 10 (33\%) students completed the material by the score of 75 or higher. $20(67 \%)$ with the score lower than 75 did not complete the material. This indicates that the learning process undertaken by teachers has not been successful.

By being aware of these problems, the teacher seeks to improve the learning process by implementing videoassisted Student Team Achievement Division (STAD).

Cooperative learning is designed to cultivate academic skill as well as social skills including interpersonal skills [3]. STAD could become one of the alternatives in solving problems that occur in learning so that in every learning can create a fun atmosphere, students are able to think logically and critically, communicate, cooperate in solving a problem. Video-assisted STAD is directed to help learners to be more active in learning and results in better outcomes [4].

STAD learning model consists of five main components including class presentations, teams, quizzes, individual progress scores, and team recognition [5]. There are eight phases of STAD in cooperative learning model, they include presentation, group, discussion, scaffolding, validation, quizzes, awards, and evaluation [3]. The purpose of the present study is to improve learners' activities and outcomes through the application of a video-assisted STAD cooperative learning model.

\section{RESEARCH METHODS}

This is a classroom action research with collaboration in nature. The researcher collaborates with peers in planning, identifying, observing, and implementing 
classroom action. Action research focuses on activities by piloting an idea into practice or real conditions on a micro scale, so it is expected that the learning activities can improve and improve the quality of teaching and learning process [6].

The research procedure contains actions of each cycle. Each cycle includes planning, observation, and reflection activities. Reflection on the first cycle can be used as a reference for action planning in the second cycle and so on [7].

The model used in this study uses a model developed by Riyanto which is a modification model from Kemmis, S. \& Mc Taggart [8].

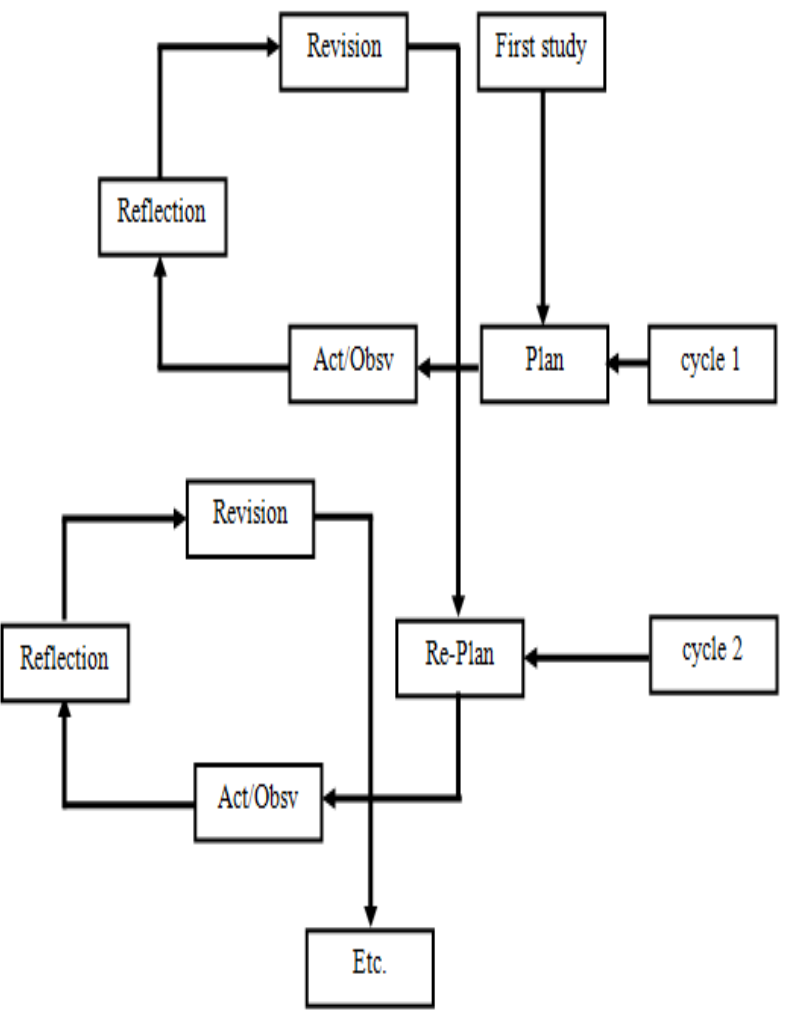

This research was conducted in IIc Class I SDN Klakahrejo I Surabaya with 30 students of 16 male and 14 female students. The research was conducted in April until May 2018. Data were collected by using observation with the assisted instrument of observation sheet, while the data collection technique of learning outcomes uses test result by giving an evaluation question after each cycle implementation. In addition, it also uses documentation technique. Documentation is important in a study to obtain data directly from the place of study. The data can be a document during the learning activities. Documentation in this research includes learning implementation plan, the photo of learning activities, and portfolio of learners activities [9].
Analysis of learners' activity data is calculated by the formula as follows.

$$
\text { Final score }=\frac{\text { Score obtained }}{\text { Maximum score }} \times 100
$$

[10]

The results of the observations are converted to the assessment criteria, as follows.

Table 3.1 Criteria of Students' Activity for Instruments

\begin{tabular}{cl}
\hline Score for Range & \multicolumn{1}{c}{ Information } \\
$20-40$ & Very low \\
$41-55$ & Low \\
$56-70$ & Medium \\
$71-85$ & Good \\
$86-100$ & Very good \\
\hline
\end{tabular}

Data analysis of learning test results is calculated using the following formula.

Score $=\frac{{ }_{B}{ }^{{ }^{J}-\frac{J_{S}}{k-1}}}{N} \times 100$

Where:

$J_{B} \quad$ : the number of items answered

$J_{S}$ : the number of items answered wrong

$\mathrm{k} \quad$ : the number of options

$\mathrm{N}$ : the number of items

The minimum completeness criteria in the curriculum of 2013 using reference criteria specified to determine the graduation of learners with national minimum completeness target are expected to reach 75 [10]. The implementation of learning is carried out in individual learning and classical learning. In the individual learning system, learners have individual mastery with a minimum score of 75 . In classical learning, the overall completeness of the total number of participants who scored 75 is compared with the number of students in the class that took the test. The minimum success rate is usually $80 \%-90 \%$ of the number of questions that should be fully answered by all learners in the classroom. Calculation of classical mastery is used as follows.

$P=\frac{\text { EStudents whose score is } \geq 75}{\sum \text { Students taking the test }} \times 100 \%$

\section{RESULT AND DISCUSSION}

1. Result

Based on the results of observation and data analysis, we can see an increase in the learning activities of learners 
through the application of video-assisted STAD cooperative learning media. Enhancement of learning activities of students from cycle I to cycle II is presented following graph.

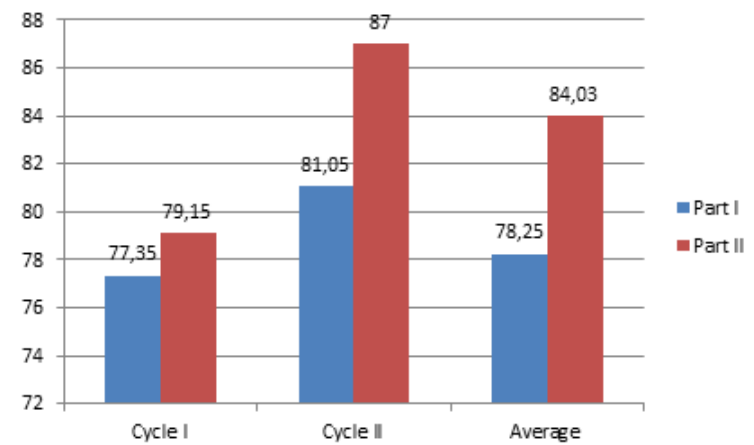

Figure 5.3 Graph of Observation Results of Cycle I and Cycle II

Improvement of student's learning outcomes and classical completeness through the application of video-assister STAD cooperative learning is drawn in the following graph.

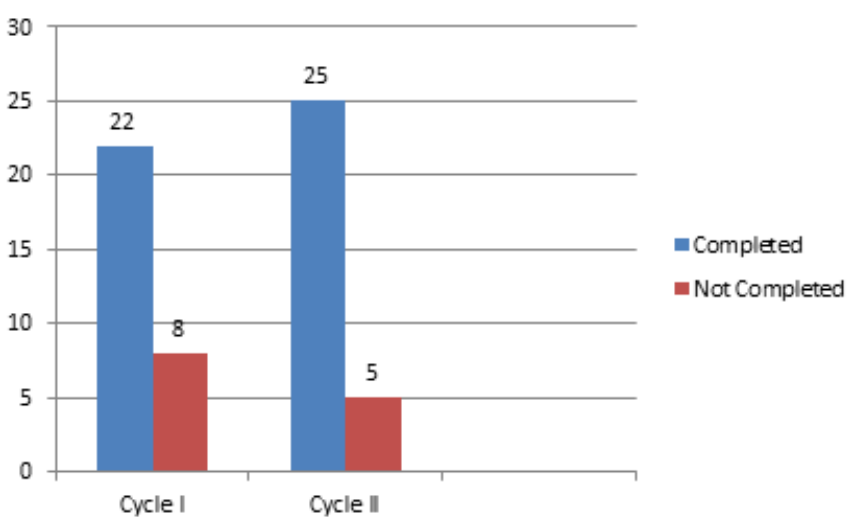

Figure 5.6 Graph of Increased Learning Outcomes in Cycle I-II

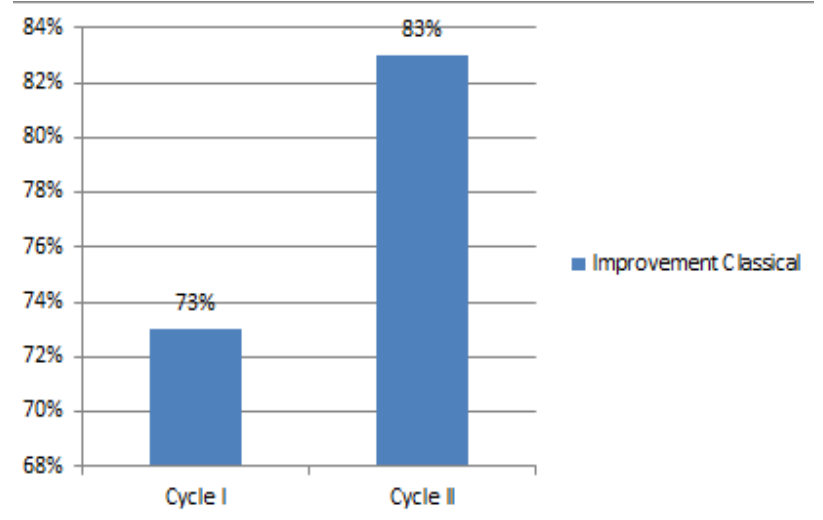

Figure 5.7 Graphic Improvement Classical Cycle I-II

\section{Discussion}

In the first cycle, the final score of the meeting I was 77.35 , increased to 79.15 in meeting II. The average score in cycle I was 78.2 while in cycle II the final score of the meeting I was 81.05 increased to 87 in meeting II. The average score on cycle II was 84.03. Based on these data, the implementation of video-assisted STAD at each meeting has increased students' outcome even in the second cycle, the increase was quite significant with the total score of 84.03 falls to good category.

Improved learning outcomes in this study are based on the results of the learning cycle I with the acquisition percentage of classical completeness of $73 \%$. Learning outcomes in cycle II result in a percentage of classical completeness of $83 \%$. Based on the results of the percentage of classical completeness, this study is successful as it has exceeded the predefined success indicator of $80 \%$ classical completeness.

\section{CONCLUSION}

Based on the results of the research discussion, learners' activity with STAD resulted an increased outcome. Students' learning outcomes by applying videoassisted STAD cooperative learning model media also increased.

\section{REFERENCES}

[1] D. W. Johnson, R. T. Johnson, and M. B. Stanne, "Cooperative learning methods: A meta-analysis." 2000.

[2] M. Abdullah and G. Jacobs, "Promoting Cooperative Learning at Primary School.," TESL-EJ, vol. 7, no. 4, p. n4, 2004.

[3] R. Yatim, "Paradigma Baru Pembelajaran Sebagai Referensi Bagi Pendidikan Dalam Implementasi Pembelajaran yang efektif dan Berkualitas," Jakarta Kencana Frenada Media Gr., 2009.

[4] Z. Zakira, J. Jamaludin, and H. Hasdin, "Meningkatkan Hasil Belajar Siswa Pada Pembelajaran PKn Melalui Metode Kooperatif Tipe Stad Pada Kelas V SDN Inpres Toropot," J. Kreat. Tadulako Online, vol. 5, no. 9.

[5] R. E. Slavin, "Cooperative learning teori, riset dan praktik," Bandung Nusa Media, vol. 236, 2005.

[6] Y. Riyanto, "Metodologi penelitian pendidikan," Surabaya Sic, vol. 318, 2001.

[7] A. Salahudin, "Penelitian Tindakan Kelas," Bandung: Pustaka Setia, 2015.

[8] R. Yatim, "Metodologi Penelitian Pendidikan Kualitatif dan Kuantitatif." Surabaya: Unesa University Press, 2007.

[9] M. B. A. Riduwan, "Skala pengukuran variabel-variabel penelitian," Alf. Bandung, 2007.

[10] T. G. Ratumanan and T. Laurens, Penilaian hasil belajar pada tingkat satuan pendidikan Edisi 3. Ambon: Pensil Komunika, 2015.

[11] M. Yamin, "Paradigma pendidikan konstruktivistik." Jakarta: Gaung Persada Press, 2008. 